\title{
C-MYC, BCL2 and BCL6 Translocation in B-cell Non-Hodgkin Lymphoma Cases
} \author{
Shiau-Chuen Cheah ${ }^{\circledR}$ \\ 1. Faculty of Medicine and Health Sciences, UCSI University, Kuala Lumpur, Malaysia. \\ 2. Advanced Molecular Pathology Laboratory, SingHealth Tissue Repository, Singapore. \\ 3. National University Hospital, Singapore. \\ 4. Sunway University Hospital, Selangor, Malaysia. \\ $\bowtie$ Corresponding author: cheahsc@ucsiuniversity.edu.my
}

Dayang Sharyati Datu Abdul Salam¹, Ei Ei Thit², Siew Hoon Teoh¹, Soo Yong Tan³, Suat Cheng Peh,

(c) The author(s). This is an open access article distributed under the terms of the Creative Commons Attribution License (https://creativecommons.org/licenses/by/4.0/). See http://ivyspring.com/terms for full terms and conditions.

Received: 2019.05.23; Accepted: 2019.09.23; Published: 2020.01.01

\begin{abstract}
C-MYC, BCL2 and BCL6 genes are the most commonly oncogenes involved in B-Cell lymphomas. Translocations of these oncogenes are associated with an aggressive clinical course. This study aims to elucidate the patterns of BCL6, BCL2 and C-MYC gene aberrations among Malaysian B-cell Non-Hodgkin Lymphoma (NHL) using fluorescence in situ hybridization (FISH). Eighty-one B-cell $\mathrm{NHL}$ tissue blocks were retrieved between the year 2011 to 2015 and investigated using immunohistochemistry and interphase FISH dual colour break-apart probes of BCL2, BCL6, C-MYC and $l g H$. A significant difference was detected between the nodal and extranodal sites in all the $B C L 2$ $(p=0.01), C-M Y C(p=0.03)$ and $\lg H(p=0.006)$ cases except for $B C L 6(p=0.2)$. Our study showed that $B C L 6$ had the highest gene translocation while BCL2/BCL6 had the most mixed aberrations of gain copies and translocation, however no mixed aberrations of gain copies and translocation was found in C-MYC. None of the mixed gain copies and translocation was found in any of the germinal centre B-cell (GCB) subtype of Diffuse Large B-cell Lymphoma, however, five were found in BCL6 and IgH gene in the non-GCB subtype; while mixed gain copies and translocation cases of $B C L 2$ gene was found in the Follicular Lymphoma cases only. The study found interesting findings of BCL2, C-MYC and $\lg \mathrm{H}$ gene aberrations between nodal and extranodal sites. This information might benefit future study in predicting prognosis and determine effective therapeutic strategies in the multi-ethnic populations of Malaysia as well as the Asian population.
\end{abstract}

Key words: B-cell Non-Hodgkin Lymphoma, C-MYC, BCL2, BCL6, gene abberation, FISH

\section{Introduction}

There has been an intense upsurge worldwide for Non-Hodgkin lymphoma (NHL) incidence approximately $2-4 \%$ annually since the last seventy years [1]. Based on the statistics presented, it was in accordance to the study done by Devesa and Fears [2] whereby western countries have the highest increased observed. Both males and females have seen an increased in all age groups however racial differences was observed in age-specific incidence curves up until the age of 45 and 35 for male and female respectively [3]. The reasons for the increase include wider use of immunohistochemical method for screening and diagnosing cancer cell type, thus leads to lesser misdiagnosis cases of NHL as well as better classification of gray-zone lymphomas [4]. In comparison to western countries, Asian countries have lower median age of NHL. The representative median age of patient in western countries was 68 years old [5]. However, the median age of NHL patient in Asian countries such as Iran, Korea and Taiwan are between 50-55 years old [6-8]. In the Global Cancer Facts $3^{\text {rd }}$ Edition [9], the global trend suggested that the increase of NHL cases in most developed countries reflects a true increase in disease 
occurrence. However, improvements in diagnostic methods and modification of classification may also play a role in the increase of NHL cases [10].

Double-hit translocation refer to translocation of $C-M Y C$ with another concurrent breakpoints such as $B C L 2, B C L 6, B C L 1$ or BCL3. Triple-hit translocation consists of $C-M Y C, B C L 2$ and $B C L 6$. Currently, these gene translocations do not have any baseline characteristics aside from the genetic profile that can be confirmed through various genetic tests such as fluorescence in situ hybridisation (FISH). Also, morphologically they are difficult to distinguish and are usually unclassifiable B-cell lymphoma of intermediate characteristic between aggressive lymphoma, Diffuse Large B-cell Lymphoma (DLBCL), and very aggressive lymphoma, Burkitt Lymphoma (BL).

$C-M Y C$ translocation of $\mathrm{t}(8 ; 14)(\mathrm{q} 24 ; \mathrm{q} 32)$ usually deregulate $C-M Y C$ expression. Rearrangement of the $C-M Y C$ gene situated on chromosome 8 next to the IgH gene, or lambda $(\lambda)$ and kappa (к) light chain genes subsequently caused upregulation of gene expression commonly observed in BL. In normal cells, $C-M Y C$ acts as a transcriptional regulator involved largely with cell cycle progression (from G1 to S phase) and the inhibition of terminal differentiation. Over-expression in normal cells sensitizes the cell to a variety of apoptotic triggers which leads the cell to resist cell death ultimately result in cancer. C-MYC gene rearrangement is reported to be rare occurrence in Follicular Lymphoma (FL). However, it was observed in $7-15 \%$ of de novo DLBCL [11] and $8 \%$ of post-transformation DLBCL [12]. Several studies reported [13,14] the presence of C-MYC gene rearrangement upon transformation. Hence, it is highly probable that $C-M Y C$ plays a vital role in transformation of high grade B-cell malignancies.

$B C L 2$ translocation, $\mathrm{t}(14 ; 18)(\mathrm{q} 32 ; \mathrm{q} 21)$, is observed in about $15-20 \%$ of DLBCL cases and approximately in $80-90 \%$ of FL cases [15]. BCL2 came from the BCL family proteins which has a crucial role in cell apoptosis. BCL2 function as a pro-survival protein, represses apoptotic cell death, and protects cell from a wide range of cytotoxic insults including cytokine deprivation, ultraviolet irradiation. Deregulation of $B C L 2$ leads to over-expression of BCL2, making the cell to resist cell death. In contrast, BCL2 inhibition eliminate cell survival advantage and allow apoptosis to occur. Similar to C-MYC translocation characteristic in DLBCL, chromosomal rearrangement that mix the $B C L 2$ gene situated on chromosome 18 involving the $\mathrm{IgH}$ gene deregulates the $\mathrm{BCL} 2$ expression [16].

Coming from the same $B C L$ family proteins, $B C L 6$ is essential for the development of germinal centre in B-cells. It acts as a transcriptional repressor in cell cycle control, proliferation and differentiation, apoptosis, and DNA damage response. Loss of normal control mechanisms regulating BCL6 expression causes lymphoproliferative disease, resembling DLBCL. BCL6 translocation, $\mathrm{t}(3 \mathrm{q} 27)$, is responsible for up to $35 \%$ of DLBCL cases, the largest compared to other DLBCL gene translocations [17]. Deregulation of BCL6 located on chromosome 3 is believed to contribute to malignant transformation in germinal center-derived B cells (GCB). Detection of point mutations of the regulatory region of the $B C L 6$ gene have been frequently found in GCB and postGCB lymphomas, including FL, DLBCL, and BL [18].

The genetic aberrations that are representative of specific subtypes of NHL mentioned previously can be identified by genetic diagnosis. Particularly, the use of FISH studies to diagnose NHL is becoming increasingly important. Interphase FISH is the most commonly applied technique for the demonstration of gene translocation, as it can be applied on paraffin embedded tissue, enabling studies on archival material. In comparison to immunohistochemical staining, interphase FISH are able to visualize gene expression pattern and can provide spatial and temporal information on understanding gene function which immunohistochemistry are not able to provide. Hence, the study aims to characterize the patterns of $B C L 6, B C L 2$ and C-MYC gene aberrations in Malaysian B-cell NHL using interphase FISH.

\section{Patients and Methods}

\section{Cases selection}

A total of 81 B-cell Non-Hodgkin Lymphoma (NHL) were retrieved from a private hospital in Penisular Malaysia laboratory, the Pantai Premier Pathology Malaysia archives between the years 2011 to 2015. The demographic data of these patients, immunohistochemistry slides and tissue blocks were obtained from the Pantai Premier Pathology database by the referring clinician. All the B-cell NHL were sectioned at $3 \mu \mathrm{m}$ for immunohistochemical staining using a panel of monoclonal and polyclonal antibodies according to Pantai Premier Pathology's standard operating procedure. For the DLBCL classification of GCB and non-GCB subtype, a panel of three antigens namely CD10, BCL6 and MUM1 was used according to Hans Criteria [19].

\section{Morphology}

The materials were cut into $4 \mu \mathrm{m}$ thick sections and stained with haematoxylin-eosin for histologic evaluation. All specimens were reviewed by a pathologist (PSC) for confirmation and classification according to the $2008 \mathrm{WHO}$ Classification of tumours of haematopoietic and lymphoid tissues [4] using 
Leica DM500 light microscope (Leica Microsystems, Switzerland) graded reticule at $x 10$ and $x 40$ magnification.

\section{Interphase FISH and scoring}

A total of 81 cases were examined using four interphase FISH dual colour break-apart probes namely BCL2/18q21, BCL6/3q27, C-MYC/8q24 and $\mathrm{IgH} / 14 q 32$ (Dako, Denmark). Haematoxylin-eosin stained tissue sections from representative formalin-fixed, paraffin-embedded tissue blocks were used to define the tumour areas. FISH analysis was performed on $2 \mu \mathrm{m}$ tissue sections using FISH DNA break-apart probes and FISH Ancillary Kit (Vysis probe, Abbott, United States). The method was carried out at Advanced Molecular Pathology Laboratory (AMPL), SingHealth, Singapore according to AMPL's standard operating procedure. Briefly, the tissue slide was de-paraffinised and rehydrated prior to the procedure. After digestion with pepsin solution, FISH DNA Probe was added to the tissue sections and hybridized for three nights followed by stringent wash. Assessment of signals was performed using Zeiss Axioimager Fluorescent microscope (Germany) with the Metasystem's ISIS Metafer software (Germany) at x63 magnification. The cases performed depend on the availability of tissue block hence the total cases for each gene were different. The FISH analyses were divided into normal, translocated ( $>20 \%$ of the whole tumour population), gain copies ( $>50 \%$ of the whole tumour population) and both translocated and gain copies category.

\section{Statistics}

Statistical analysis was completed using GraphPad Prism software (version 5.0; GraphPad Software Inc., San Diego, CA). $\chi^{2}$ or Fisher's exact tests were used for categorical parameters to identify significant relationships between variables. P value < 0.05 was considered statistically significant.

\section{Results}

\section{Patients' Characteristics}

The patients' demographic and clinical characteristics are summarized in Table 1. Among the 81 patients, there were 42 males $(51.9 \%)$ and 39 females $(48.1 \%)$ in this study. The male:female ratio is 1.08:1 and age ranged from 10-92 (median age of 55.8). The ethnic distribution were as follow: 23 Malays (28.4\%), 42 Chinese (51.9\%), 4 Indians (4.9\%) and 12 Others consisted of Bumiputera and foreigners with undetermined country of origin $(14.8 \%)$. There were 57 DLBCL cases $(70 \%), 15$ FL cases $(19 \%), 1$ BL case (1\%), 1 DLBCL-BL like case (1\%), 4 Marginal Zone Lymphoma (MZL) case (5\%), 1 Mucosa-Associated
Lymphoid Tissue (MALT) cases (1\%), 1 Mediastinal B-cell Lymphoma case $(1 \%)$ and 1 DLBCL-Plasmablastic Lymphoma case (1\%). In terms of lymphoma sites, B-cell lymphoma originating from nodal sites was $42(52 \%)$ and extranodal sites was 39 (48\%). The most common extranodal sites are gastrointestinal (12 cases, $31 \%$ ) and Waldeyer's ring (8 cases, $21 \%$ ) and 19 others for example in the brain or spleen.

Table 1. Demographic and clinical characteristic of 81 patients with B-Cell NHL

\begin{tabular}{ll}
\hline & $\mathbf{N}(\%)$ \\
\hline Gender & $42(52)$ \\
Male & $39(48)$ \\
Female & \\
Age & $48(59)$ \\
$<60$ years & $33(41)$ \\
$\geq 60$ years & \\
Ethnic & $23(28)$ \\
Malay & $42(52)$ \\
Chinese & $4(5)$ \\
Indian & $12(15)$ \\
Others & \\
Sites & $42(52)$ \\
Nodal & $39(48)$ \\
Extranodal & \\
\hline
\end{tabular}

\section{Prevalence of BCL2 I BCL6 / C-MYC / IgH gene aberrations}

A summary of all the FISH prevalence are given in Table 2. Out of the 81 cases, only 73 cases had successful BCL2 FISH assay, 67 patients had successful BCL6 FISH assay, 72 successful FISH assay were collected for $C-M Y C$ and 64 cases had successful $\mathrm{IgH}$ FISH assay. In DLBCL cases, BCL6 and IgH gene aberrations recorded the highest with 19 and 20 cases respectively. In terms of DLBCL cell-of-origin (COO) classification, there was no significant difference between the gene aberrations to GCB and non-GCB type except for BCL6 $\left(p=0.03^{*}\right)$. BCL2 and $I g H$ were the highest gene aberrations in FL cases with 6 and 7 cases respectively. One $B C L 2$ gene aberrations was found in MZL and one C-MYC and $I g H$ gene aberrations were found in a BL case. Although female had slightly higher $C-M Y C$ and $I g H$ gene aberrations compared to male, there was no significant difference found between them. While, Chinese had the highest gene aberrations in all the FISH BCL2, BCL6, C-MYC and $\mathrm{IgH}$ assays although there was no significant difference found among the Malaysian ethnics. Significant difference was detected between the nodal and extranodal sites in all the BCL2 $\left(p=0.01^{* *}\right), C-M Y C$ $\left(p=0.03^{*}\right)$ and $\operatorname{IgH}\left(p=0.006^{* *}\right)$ except for BCL6 $(p=0.2)$, although higher BCL6 gene aberrations were found in the nodal compared to extranodal sites. 
Table 2. Prevalence of $B C L 2$ / BCL6 / C-MYC / IgH gene aberrations in B-Cell NHL patients

\begin{tabular}{|c|c|c|c|c|c|c|c|c|}
\hline & \multicolumn{2}{|c|}{$B C L 2(n=73)$} & \multicolumn{2}{|c|}{$B C L 6(n=67)$} & \multicolumn{2}{|c|}{$C-M Y C(\mathrm{n}=72)$} & \multicolumn{2}{|c|}{$\operatorname{IgH}(\mathrm{n}=64)$} \\
\hline & $\begin{array}{l}\text { Normal } \\
\text { N (\%) }\end{array}$ & $\begin{array}{l}\text { Aberrations } \\
\text { N (\%) }\end{array}$ & $\begin{array}{l}\text { Normal } \\
\text { N (\%) }\end{array}$ & $\begin{array}{l}\text { Aberrations } \\
\text { N (\%) }\end{array}$ & $\begin{array}{l}\text { Normal } \\
\text { N (\%) }\end{array}$ & $\begin{array}{l}\text { Aberrations } \\
\text { N (\%) }\end{array}$ & $\begin{array}{l}\text { Normal } \\
\text { N (\%) }\end{array}$ & $\begin{array}{l}\text { Aberrations } \\
\text { N (\%) }\end{array}$ \\
\hline B-cell NHL & \multicolumn{2}{|l|}{$p=0.22$} & \multicolumn{2}{|l|}{$p=0.06$} & \multicolumn{2}{|l|}{$p=0.87$} & \multicolumn{2}{|l|}{$p=0.06$} \\
\hline DLBCL & $35(48)$ & $16(22)$ & $28(42)$ & $19(28)$ & $41(57)$ & $9(13)$ & $24(38)$ & $20(31)$ \\
\hline FL & $7(10)$ & $6(8)$ & $7(10)$ & $4(6)$ & $11(15)$ & $2(3)$ & $4(6)$ & $7(11)$ \\
\hline Others & $8(11)$ & $1(1)$ & $9(13)$ & $0(0)$ & $8(11)$ & $1(1)$ & $8(13)$ & $1(2)$ \\
\hline Gender & \multicolumn{2}{|l|}{$p=1.0$} & \multicolumn{2}{|l|}{$p=0.8$} & \multicolumn{2}{|l|}{$p=0.54$} & \multicolumn{2}{|l|}{$p=0.46$} \\
\hline Male & $25(34)$ & $12(16)$ & $21(31)$ & $12(18)$ & $32(44)$ & $5(7)$ & $19(30)$ & $12(19)$ \\
\hline Female & $25(34)$ & $11(15)$ & $23(34)$ & $11(16)$ & $28(39)$ & $7(10)$ & $17(27)$ & $16(25)$ \\
\hline DLBCL COO & \multicolumn{2}{|c|}{$p=0.47(\mathrm{n}=51)$} & \multicolumn{2}{|c|}{$p=0.03^{*}(\mathrm{n}=47)$} & \multicolumn{2}{|c|}{$p=0.43(\mathrm{n}=50)$} & \multicolumn{2}{|c|}{$p=0.73(\mathrm{n}=44)$} \\
\hline GCB & $9(18)$ & $2(4)$ & $10(21)$ & $1(2)$ & $11(22)$ & $1(2)$ & $6(14)$ & $4(9)$ \\
\hline Non-GCB & $26(51)$ & $14(28)$ & $18(38)$ & $18(38)$ & $30(60)$ & $8(16)$ & $18(41)$ & $16(36)$ \\
\hline Site & \multicolumn{2}{|l|}{$p=0.01^{*}$} & \multicolumn{2}{|l|}{$p=0.2$} & \multicolumn{2}{|l|}{$p=0.03^{*}$} & \multicolumn{2}{|c|}{$p=0.006^{*}$} \\
\hline Nodal & 21 (29) & $17(23)$ & $21(31)$ & $15(22)$ & $29(40)$ & $10(14)$ & $14(22)$ & $21(33)$ \\
\hline Extranodal & $29(40)$ & $6(8)$ & $23(34)$ & $8(12)$ & $31(43)$ & $2(3)$ & $22(34)$ & 7 (11) \\
\hline Ethnic & \multicolumn{2}{|l|}{$p=0.54$} & \multicolumn{2}{|l|}{$p=0.78$} & \multicolumn{2}{|l|}{$p=0.49$} & \multicolumn{2}{|l|}{$p=0.17$} \\
\hline Malay & $12(16)$ & $7(10)$ & 13 (19) & $6(9)$ & $15(21)$ & $4(6)$ & $13(20)$ & $5(8)$ \\
\hline Chinese & $26(36)$ & $13(18)$ & $21(31)$ & 13 (19) & $31(43)$ & $7(10)$ & $18(28)$ & $15(23)$ \\
\hline Others & $12(16)$ & $3(4)$ & $10(15)$ & $4(6)$ & $14(19)$ & $1(1)$ & $5(8)$ & $8(13)$ \\
\hline
\end{tabular}

COO, cell-of-origin

Table 3. FISH analysis of $B C L 2, B C L 6, C-M Y C$ and $\lg H$ gene aberrations

\begin{tabular}{|c|c|c|c|}
\hline & $\begin{array}{l}\text { DLBCL, } n=57 \\
\text { N (\%) }\end{array}$ & $\begin{array}{l}\text { FL, } \mathbf{n = 1 5} \\
\mathrm{N}(\%)\end{array}$ & $\begin{array}{l}\text { Others, } n=9 \\
N(\%)\end{array}$ \\
\hline \multicolumn{4}{|l|}{ BCL-2 } \\
\hline Gain & $13(22.8 \%)$ & 0 & $1(11.1 \%) * \mathrm{MZL}$ \\
\hline Translocated & $3(5.3 \%)$ & $4(26.7 \%)$ & 0 \\
\hline \multicolumn{4}{|l|}{ BCL-6 } \\
\hline Gain & $6(10.5 \%)$ & $1(6.7 \%)$ & 0 \\
\hline Translocated & $10(17.5 \%)$ & $3(20.0 \%)$ & 0 \\
\hline \multicolumn{3}{|l|}{ C-MYC } & 0 \\
\hline Gain & $5(8.8 \%)$ & $2(13.3 \%)$ & 0 \\
\hline Translocated & $4(7.0 \%)$ & 0 & $1(11.1 \%) * B L$ \\
\hline \multicolumn{4}{|l|}{ IgH } \\
\hline Gain & $1(1.8 \%)$ & $0(0.0 \%)$ & 0 \\
\hline Translocated & $17(29.8 \%)$ & $7(46.7 \%)$ & $1(11.1 \%) * B L$ \\
\hline Translocated \& Gain & $2(3.5 \%)$ & 0 & 0 \\
\hline
\end{tabular}

MZL, Marginal Zone Lymphoma; BL, Burkitt Lymphoma

\section{Analyses of BCL2 I BCL6 / C-MYC and IgH gene aberrations}

Table 3 summarised the FISH analysis of BCL2, $B C L 6, C-M Y C$ and $I g H$ gene aberrations according to NHL subtypes. Among the 57 DLBCL cases, there were 13 BCL2 gain $(22.8 \%)$ and $3(5.3 \%)$ BCL2 translocated cases. While, FL had $4(26.7 \%)$ BCL2 translocated cases and $2(13.3 \%) B C L 2$ translocated and gain cases. In addition, 1 BCL2 gain case was found in MZL. On the other hand, there were 6 BCL6 gain $(10.5 \%), 10(17.5 \%)$ BCL6 translocated cases and 3 (5.3\%) BCL6 translocated and gain. While, FL had 3 (20\%) BCL6 translocated cases and 1 (6.7\%) BCL6 gain case. There was no BCL6 gene abnormalities found in Other NHL subtypes. In the 57 DLBCL cases for $C-M Y C$ aberrations, there were $5(8.8 \%)$ C-MYC gain and $4(7.0 \%)$ C-MYC translocated cases. While, FL had only $2(13.3 \%)$ C-MYC gain cases. In addition, 1 $C-M Y C$ translocated case was found in BL. While for the $\mathrm{IgH}$ gene abnormalities, among the 57 DLBCL cases, there were 1 (1.8\%) IgH gain, 17 (29.8\%) IgH translocated and $2(3.5 \%) \mathrm{IgH}$ translocated and gain cases. Apart from that, FL had only 7 (26.7\%) IgH translocated cases.

\section{Double and triple aberrations among $B C L 2$, $B C L 6$ and C-MYC}

There were 16 cases found to have concurrent genetic aberrations through FISH analyses on BCL2, $B C L 6$ and C-MYC. These cases were investigated further by doing comparison of their immunephenotype and genetic features as shown in Table 4 while summary of the gene aberrations are shown in Table 5 . Of the 16 cases, 13 were DLBCL and 3 were FL cases. There was equal proportion of male and female however higher aberrations were found in the nodal sites (12 cases) than extranodal sites (4 cases).

One double-hit lymphoma of BCL6/C-MYC was established in DLBCL Case 6 (Fig 1), however both of the BCL6/C-MYC protein expression showed less than $50 \%$ and $40 \%$ respectively with Ki67 of $40 \%$. Apart from that, two translocation of BCL2/BCL6 (Case 3 and Case 14) cases were found with the Case 14 having additional 3-4 gain copies of $C-M Y C$. The corresponding BCL2/BCL6 co-expression show positive expression (Case 3 ) and more than cut-off values (Case 14). There were three cases (Case 7, 12 and 15) showing triple gene aberrations of $B C L 2 / B C L 6 / C-M Y C$ with at least 3 gain copies of chromosome or trisomy 3 . The three cases corresponding protein expression presented more than $70 \%$ BCL2, more than $40 \%$ C-MYC and all were non-GCB subtypes. 

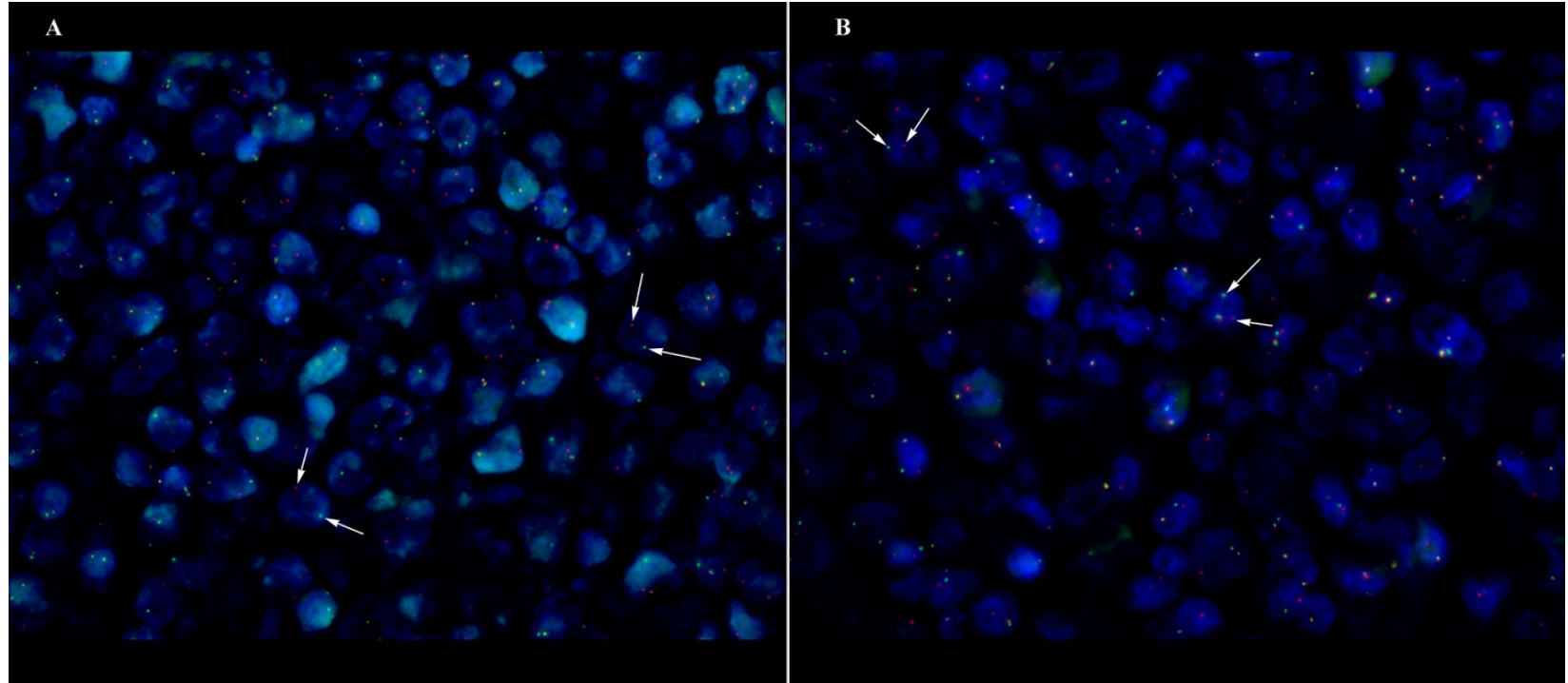

Figure 1. DLBCL case of GCB origin with double-hit C-MYC/BCL6 translocation (Case 6) at x63 magnification. White arrow shows the discrete red and green signals. (A) C-MYC translocation (B) BCL6 translocation.

Table 4. Immunohistochemical and genetic features of the $16 \mathrm{DLBCL}$ and FL cases

\begin{tabular}{|c|c|c|c|c|c|c|c|c|c|}
\hline \multirow[t]{2}{*}{ No. } & \multirow[t]{2}{*}{ Diagnosis } & \multicolumn{2}{|l|}{$B C L 2$} & \multicolumn{2}{|l|}{ BCL6 } & \multicolumn{2}{|c|}{$C-M Y C$} & \multirow{2}{*}{$\begin{array}{l}\text { Ki67 } \\
\text { IHC }\end{array}$} & \multirow{2}{*}{$\begin{array}{l}\text { IgH } \\
\underline{\text { FISH }}\end{array}$} \\
\hline & & IHC & $\underline{\text { FISH }}$ & IHC & FISH & IHC & FISH & & \\
\hline Case 1 & FL & positive & $T \& G$ & positive & $x$ & $x$ & $\mathrm{G}(3-4 \mathrm{cp})$ & $x$ & $x$ \\
\hline Case 2 & FL & positive & $\mathrm{T}$ & positive & $\mathrm{N}$ & $x$ & $\mathrm{G}$ (up to $3 \mathrm{cp}$ ) & $>80$ & $\mathrm{~T}$ \\
\hline Case 3 & FL & positive & $\mathrm{T}$ & positive & $\mathrm{T}$ & $x$ & $\mathrm{~N}$ & 50 & $\mathrm{~T}$ \\
\hline Case 4 & DLBCL & $>70 \%$ & $\mathrm{G}$ (up to $3 \mathrm{cp}$ ) & $<50 \%$ & $\mathrm{G}(3-4 \mathrm{cp})$ & $<40 \%$ & $\mathrm{~N}$ & $>90$ & $x$ \\
\hline Case 5 & DLBCL & $>70 \%$ & $\mathrm{G}(2-3 \mathrm{cp})$ & $<50 \%$ & $\mathrm{~T}$ & $<40 \%$ & $\mathrm{~N}$ & $>90$ & $\mathrm{~N}$ \\
\hline Case 6 & DLBCL & $>70 \%$ & $\mathrm{~N}$ & $<50 \%$ & $\mathrm{~T}$ & $<40 \%$ & $\mathrm{~T}$ & 40 & $\mathrm{~T}$ \\
\hline Case 7 & DLBCL & $>70 \%$ & $\mathrm{G}(3-4 \mathrm{cp})$ & $>50 \%$ & $\mathrm{G}(3-4 \mathrm{cp})$ & $>40 \%$ & $\mathrm{G}(3-4 \mathrm{cp})$ & 50 & $G(3-4 c p)$ \\
\hline Case 8 & DLBCL & $>70 \%$ & $\mathrm{G}$ (up to $3 \mathrm{cp}$ ) & $\sim 50 \%$ & $\mathrm{x}$ & $<40 \%$ & $\mathrm{~T}$ & $>80$ & $\mathrm{x}$ \\
\hline Case 9 & DLBCL & $>70 \%$ & $\mathrm{G}(2-3 \mathrm{cp})$ & $>50 \%$ & $\mathrm{~N}$ & $>40 \%$ & $\mathrm{~T}$ & $\sim 50$ & $\mathrm{~N}$ \\
\hline Case 10 & DLBCL & $>70 \%$ & $\mathrm{G}(3-4 \mathrm{cp})$ & $\sim 50 \%$ & $\mathrm{~T} \& \mathrm{G}$ & $<40 \%$ & $\mathrm{~N}$ & $>95$ & $\mathrm{~N}$ \\
\hline Case 11 & DLBCL & $>70 \%$ & $G(3-4 c p)$ & $>50 \%$ & $G(2-3 c p)$ & $>40 \%$ & $\mathrm{~N}$ & 90 & $\mathrm{~N}$ \\
\hline Case 12 & DLBCL & $>70 \%$ & $G(4-5 c p)$ & $>50 \%$ & $\mathrm{G}$ (up to $3 \mathrm{cp}$ ) & $>40 \%$ & $\mathrm{G}$ (up to $3 \mathrm{cp}$ ) & $\sim 100$ & $\mathrm{~N}$ \\
\hline Case 13 & DLBCL & $>70 \%$ & $\mathrm{G}(4-5 \mathrm{cp})$ & $>50 \%$ & $\mathrm{~T} \& \mathrm{G}$ & $>40 \%$ & $\mathrm{G}(3-4 \mathrm{cp})$ & $\sim 100$ & $\mathrm{~T} \& \mathrm{G}$ \\
\hline Case 14 & DLBCL & $>70 \%$ & $\mathrm{~T}$ & $>50 \%$ & $\mathrm{~T}$ & $<40 \%$ & $\mathrm{G}(3-4 \mathrm{cp})$ & $>90$ & $\mathrm{~T}$ \\
\hline Case 15 & DLBCL & $\sim 70 \%$ & $G(5-6 c p)$ & $<50 \%$ & $\mathrm{G}$ (up to $3 \mathrm{cp}$ ) & $>40 \%$ & $\mathrm{G}(3-4 \mathrm{cp})$ & $x$ & $T \& G$ \\
\hline Case 16 & DLBCL & $>70 \%$ & $\mathrm{G}(3-5 \mathrm{cp})$ & $\sim 50 \%$ & $\mathrm{~T} \& \mathrm{G}$ & $<40 \%$ & $\mathrm{~N}$ & 80 & $\mathrm{~N}$ \\
\hline
\end{tabular}

N, Normal; G, Gain copies; T, Translocation; T\&G, Translocation \& Gain copies; cp, copies; X, Missing/No tissue left

Table 5. Summarise of gene abnormalities among BCL2 / BCL6 / C-MYC / IgH in 16 cases of B-cell NHL

\begin{tabular}{ll}
\hline & N \\
\hline & Male (n=8), Female (n=8) \\
Nodal (n=12), Extranodal (n=4) \\
BCL2/BCL6 & \\
BCL2/BCL6 - (G) & 2 \\
BCL2/BCL6 - (T) & 1 \\
BCL2 (G) / BCL6 (T) & 1 \\
BCL2 (G) / BCL6 (T\&G) & 2 \\
BCL2/C-MYC & \\
BCL2 (G) / C-MYC (T) & 2 \\
BCL2 (T) / C-MYC (G) & 1 \\
BCL2 (T\&G) / C-MYC (G) & 1 \\
BCL6/C-MYC & \\
BCL6/C-MYC - (T) & 1 \\
BCL2/BCL6/C-MYC & \\
BCL2/ BCL6/C-MYC - (G) & 3 \\
BCL2/C-MYC (G) \& BCL6 (T\&G) & 1 \\
BCL2/ BCL6 (T) \& C-MYC (G) & 1 \\
\hline
\end{tabular}

Comparing the genetic aberrations with the protein expression of the 16 cases showed that all of the 16 cases had positive protein expression for both BCL2 and BCL6. In the 13 cases of DLBCL, all of them had BCL2 protein expression of more than $70 \% .9$ DLBCL cases had BCL6 protein expression of more than $50 \%$ and only 6 DLBCL cases had more than $40 \%$ C-MYC protein expression. In the FL cases, 2 had $B C L 2 / C-M Y C$ gene aberrations and the other had $B C L 2 / B C L 6$ translocation. In the cases involving extranodal sites, all 4 cases had gain chromosomes of at least 3 copies in BCL2. BCL2/BCL6 had the highest gene aberrations combination (6 cases) compared to BCL2/C-MYC (4 cases) or BCL6/C-MYC (1 case). With the exception of Case 1, 6 and 15, the cell proliferation for the 16 cases showed at least 50\% Ki67 index.

G, Gain copies; T, Translocation; R\&G, Translocation \& Gain copies 


\section{Discussion}

In the present study, we reported the prevalence and genetic abnormalities of 81 cases of B-cell NHL among Malaysian patients using interphase FISH. Our findings revealed there was a significant difference detected between the nodal and extranodal sites in BCL2, C-MYC and $I g H$. The findings coincide with a study [20] investigating on metaphase comparative genomic hybridization ( $\mathrm{CGH}$ ) and their results showed nodal sites having more frequent amplifications than extranodal particularly of BCL2. The differences could readily be explained by the alterations in the behaviour of the cell types from the sites they develop [21]. The findings connected previous evidences $[22,23]$ that high gene aberrations at site-specific lymphomas may increase the number of lymphocytes, hence higher chances of a malignant clone developing. In addition, certain local factors such as exposure to numerous types of antigens and activation of the B-cell receptor (BcR) signalling pathway are known to increase the risk of lymphomas at nodal or extranodal sites [24]. This is important as extranodal lymphoma is distinctive from nodal in numerous ways, such as in treatment strategies and prognosis. Apart from that, it is shown that among Asian population, extranodal sites such as gastrointestinal tract, nasal cavity and tonsils are the commonest sites and have high incidence compared to nodal sites [25]. Undoubtedly, there is more to be learned of DLBCL pathogenesis at distinct extranodal sites since there is also emerging cases of differences and similarities in somatic genetic abnormalities particularly between DLBCL arising at different sites $[26,27]$. However, there is little evidence in these data to suggest that aberrations in the nodal and extranodal sites could have effects on the clinical course and survival due to insufficient information of the patients.

BCL2 translocation was found in $40 \%$ and $32 \%$ of our $13 \mathrm{FL}$ and 51 DLBCL cases respectively. The BCL2 translocation is the cytogenetic hallmark for approximately $90 \%$ of FL cases. Although the incidence of FL among Asian is considerably smaller compared to Caucasian, a Japanese study [28] found high $(81 \%)$ BCL2 translocated FL cases using FISH analysis in contrast to our FL findings with only $40 \%$ BCL2 translocation. Similar findings in the Western countries, Germany [29] generated quite similar results with only $53 \%$ of $B C L 2$ translocation in early stage FL cases. Apart from the reason that we had considerably low FL sample size, it was also suggested that the discrepancy between the findings could be due to technique differences as suggested by a study [30] that investigated variations of the BCL2 translocation incidence in FL. Aster and Longtine [30] examined data using methods that eliminate most false-negative results by detecting BCL2 sequence rearrangements outside of the MBR (major breakpoints) and mcr (minor breakpoints) sites. In addition, $B C L 2$ translocation is not sufficient to cause B-cells transformation as seen in BCL2 transgenic mice, which only develop lymphomas after secondary chromosome modifications and long latency period [31]. Marin et al. [32] and Tanaka et al. [33] have both established in vivo that BCL2 deregulation caused by translocation of $B C L 2$ increases cell survival by preventing apoptosis, prompting the cell to acquire secondary chromosomal aberrations. BCL2 gene aberrations, other than $\mathrm{t}(14 ; 18)(\mathrm{q} 32 ; \mathrm{q} 21)$, such as $18 \mathrm{q} 21$ amplification or activation of the nuclear factor-kB pathway, has been suggested to be the main responsible act for dysregulation of BCL2 protein expression in the DLBCL non-GCB subtype [34].

It was also found that in our FISH analysis of 50 DLBCL cases, the frequency of C-MYC aberrations of $18 \%$ was quite similar to what have been reported in Western populations [35]. C-MYC rearrangement at band $8 \mathrm{q} 24$, is associated with a poor prognosis and reported in approximately 15\% of DLBCL cases [35]. However, supported data to incriminate geographical or genetical factors between DLBCL in South East Asian and in Western countries needs further observation that can be confirmed in larger studies. Deregulation of C-MYC has been implicated with aggressive lymphomas and adverse prognosis in B-cell malignancies as it plays a role by promoting cell cyle progression and tumour proliferation in DLBCL. Using the same samples, we had identified the MYC involvement in STAT3-mediated pathway in EBV (+)-DLBCL cases [36]. Substantial evidence [37] of both in vitro and in vivo models have provided that MYC prompts many genes that involved in ribosome biogenesis including genes associated in glucose and glutamine metabolism to accommodate the growing lymphoma cells. Translocation of $M Y C$ has been described as the genetic hallmark and the driving oncogene for BL [38] as presented in our only BL case. BL is a germinal center tumour harbouring somatic hypermutation of the $I g$ genes and is characterized by the presence $M Y C$ and $I g H$ translocation. Although, $C-M Y C$ is the defining feature to $\mathrm{BL}$, it has also been recognized in other NHL B-cell lymphomas such as DLBCL and FL whereby MYC overexpression has been associated in the transformation of FL [39].

On the other hand, there was no significant difference for BCL6 gene aberrations found between the nodal and extranodal sites. BCL6 translocation and clinical features of B-cell NHL particularly DLBCL has been the subject of controversy. Several studies $[40,41]$ reported that BCL6 gene translocations 
occured frequently in extranodal than in nodal sites. Subsequent studies by Offit et al. [42] found that extranodal DLBCL patients had more frequent gene rearrangements than those found in the nodal sites of DLBCL. However, contradicting report [43] which also supported findings in this study found that there was no difference in the BCL6 translocation between the DLBCL sites.

Our DLBCL findings also revealed that BCL6 had the highest gene translocation (40\%) compared to $B C L 2$ and C-MYC. The incidence of BCL6 translocation in our study supported the evidence that BCL6 gene translocation in B-Cell NHL constituted about $30-40 \%$ of all DLBCL $[44,45]$. In addition, $6 \%$ of our FL cases also had BCL6 gene aberrations. Although it is unusual, previous study showed that $5-15 \%$ of FL patients had BCL6 rearrangement that occurred in the both low-grade and high-grade FL $[29,46]$. It was suggested that FL cases with translocation other than BCL2 may have unconventional molecular mechanisms or at least an alternate initiating event of FL [29]. About 13 out of 23 cases of the BCL6 gene aberrations in this study involved $\mathrm{IgH}$ gene while the rest are with $B C L 2$ and $C-M Y C$, showing the diversity of BCL6 translocation partner as mentioned by Cattoretti et al. [47]. It is identified that non- $\mathrm{IgH} / \mathrm{BCL} 6$ translocated cases are under the effect of the regulatory regions in BCL6 and some of these partner genes expression have role(s) in the development of DLBCL [48,49]. BCL6 gene rearrangement has been associated with poor prognosis when a study [50] evaluating BCL6 translocation using FISH analysis found that translocation of BCL6 in DLBCL patients had significantly lower overall survival than those without translocation. Consistent to what has been mentioned previously [51], we found significant higher $B C L 6$ gene abnormalities in non-GCB subtype $(38 \%)$ than in GCB subtype $(2 \%)(p=0.03)$, suggesting that the DLBCL GCB and non-GCB subtype have separate molecular mechanisms of DLBCL pathogenesis responsible for the abnormal protein expression. However, $B C L 6$ gene aberrations were not correlated with high BCL6 expression level in our study $(\mathrm{p}=1.00)$. Akyurek et al. [52] reported that there was no correlation between BCL6 rearrangement with the level of BCL6 protein expression. However, this discrepancy can also arise due to the differences in the staining and scoring methodologies, cut-off values, and sample populations.

There were also 8 cases with $\operatorname{IgH}$ only gene aberrations which warrant further investigations. It is known that $\mathrm{IgH}$ is the first rearranged gene in B-cell development and an early marker of clonal B lymphoid processes, with light chain genes for $\kappa$ and $\lambda$ chains occurring only after heavy chain gene rearrangement has occurred through allelic exclusion [53]. Under normal circumstances, only one of the two $\mathrm{IgH}$ alleles is functional due to its monoallelical nature and to facilitate allelic exclusion, the other allele is non-functional for several reasons, in this particular case the non-functional allele is translocated but encoded on a dysfunctional Ig chain therefore cannot be assembled into a surface-expressed $\mathrm{BcR}$ or an antibody [54]. Another reason $\mathrm{IgH}$-specific gene aberrations could occur was due to the problematic nature of the FISH IgH probe whereby we used three times signal diameter for $\operatorname{IgH}$ image analysis confirmation of translocation in our study. Due to the unique mechanism of $\mathrm{V}(\mathrm{D}) \mathrm{J}$ recombination, the green signals will be weak due to deletion. Sometimes following a translocation, a signal may be lost as the derivative partner chromosome is deleted or if the probe has been deleted by recombination. Hence, $I g H$ green probe may faintly cross hybridise with small regions located on 15q11.2 and 16p11.2 showing tiny green dots accompanying the larger $\mathrm{IgH}$ green signals.

With regards to double or triple aberrations among the three genes, our study had one double-hit lymphoma of BCL6/C-MYC found in DLBCL Case 6, with both of the BCL6/C-MYC protein expression showing less than $50 \%$ and $40 \%$ respectively and Ki67 of $40 \%$. The BCL6 and C-MYC cut-off values were carefully considered and adopted from previous studies [55,56] investigating the C-MYC, BCL2 and BCL6 expression in DLBCL patients. In addition, our study also found two cases harbouring both $B C L 2 / B C L 6$ translocation at the nodal site. One of this $B C L 2 / B C L 6$ double translocation were discovered in low grade FL case which was in accordance with previous studies [57-59] that reported the BCL2/BCL6 translocation was predominantly low grade FL. Although there are contrasting evidence with regards to $B C L 2$ and $B C L 6$ rearrangement prognostic impact [50], consensus exist that $C-M Y C$ rearrangement is the worse prognostic marker for DLBCL patients treated with either standard CHOP or R-CHOP[5].

Pfreundschuh [60] mentioned that, apart from translocation, FISH failed to detect other gene aberrations; however our study found other types of $C-M Y C, B C L 2$ and BCL6 gene aberrations such as gain copies which was detected through FISH break-apart probe analyses. There were three DLBCL cases having at least trisomy 3 of $B C L 2 / B C L 6 / C-M Y C$ and all were non-GCB subtypes. Asian and Western [61] studies revealed that the $\mathrm{ABC}$ subtype of DLBCL has frequent trisomy 3 especially involving chromosome 3 (BCL6) and 18 (BCL2) as defined by gene expression profiling. On the other hand, the small population of the GCB subtype in this study was found to be less compared 
to the non-GCB subtype, consistent with previous studies [62] on the prevalence of GCB-subtype on Asian patients. It was found that Asian DLBCL patients had less frequent GCB subtype compared to Caucasian patients, a difference that may be attributed to ethnic factors.

In summary, few interesting patterns emerged that should be interpreted with caution. Our data suggest that there is a significant difference between the sites of lymphoma hence suggest that lymphoma sites played an important role for gene abnormalities for $B C L 2, C-M Y C$ and $I g H$. In support with other previous studies, $B C L 6$ remained the highest gene aberrations for B-cell NHL and BCL2/BCL6 gene aberrations frequently occurred compared to other gene aberrations combinations. Since this is a retrospective study and we do not correlate our results with survival data of the patients, we are not able to establish prognostic implications particularly of a nodal genetic signature. However, our report on the incidence and pattern of BCL6, BCL2 and C-MYC genes can serve as a platform for future studies to predict prognosis and determine therapeutic strategies in the multi-ethnic population of Malaysia as well as the diverse Asian population.

\section{Acknowledgments}

Many thanks to Pavithra Mahendran, Puan Rohaidah (Pantai Premier Pathology Lab) and Fatin (Pantai Premier Pathology Lab), Magdalene Koh (AMPL) and Frecila Aquino Figueroa (AMPL) for their expert technical assistance.

\section{Ethics}

The studies complied with all provisions of the Declaration of Helsinki and were approved by UCSI University Faculty of Medicine and Health Science Ethics Committee.

\section{Funding}

This work was funded by Malaysia Ministry of Higher Education (MOHE) Fundamental Research Grant Scheme (FRGS) FRGS/1/2014/SKK06/UCSI/ $01 / 1$. The funders had no role in study design, data collection and analysis, decision to publish, or preparation of the manuscript.

\section{Author contributions}

DS: Designed and performed the experiments, wrote the manuscript, analysed the data. EET: Performed experiments, analysed the data. SHT: Performed experiments. SCP, TSY: Conceived and designed the experiment, Pathology reference panel. SCC: Conceived and designed the experiment, Contributed reagents/materials/analysis tool.

\section{Competing Interests}

The authors have declared that no competing interest exists.

\section{References}

1. Baris D, Zahm SH. Epidemiology of lymphomas. Curr Opin Oncol. 2000; 12(5): 383-94.

2. Devesa SS, Fears T. Non-Hodgkin's lymphoma time trends: United States and international data. Cancer Res. 1992; 52(19 Suppl): 5432s-40s.

3. Müller AM, Ihorst G, Mertelsmann R, Engelhardt M. Epidemiology of non-Hodgkin's lymphoma (NHL): trends, geographic distribution, and etiology. Ann Hematol. 2005; 84(1): 1-12.

4. Swerdlow SH, Campo E, Harris NL, Jaffe ES, Pileri SA, Stein H, et al. WHO classification of tumours of haematopoietic and lymphoid tissues. France: IARC Press; 2008 Sep 20.

5. Smith A, Roman E, Howell D, Jones R, Patmore R, Jack A, et al. The Haematological Malignancy Research Network (HMRN): a new information strategy for population based epidemiology and health service research. Br J Haematol. 2010; 148(5): 739-53.

6. Ko YH, Kim CW, Park CS, Jang HK, Lee SS, Kim SH, et al. REAL classification of malignant lymphomas in the Republic of Korea: incidence of recently recognized entities and changes in clinicopathologic features. Hematolymphoreticular Study Group of the Korean Society of Pathologists. Revised European-American lymphoma. Cancer. 1998; 83(4): 806-12.

7. Lee MY, Tan TD, Feng AC, Liu MC. Clinicopathological analysis of malignant lymphoma in Taiwan, defined according to the World Health Organization classification. Haematologica. 2005; 90(12): 1703-5.

8. Mozaheb Z. Epidemiology of Lymphoid Malignancy in Asia. Epidemiology Insights. Maria de Lourdes Ribeiro de Souza da Cunha, IntechOpen; 2012.

9. American Cancer Society. Global Cancer Facts \& Figures 3rd Edition. Atlanta, USA: Am Cancer Soc; 2015.

10. Hartge P, Devesa SS. Quantification of the impact of known risk factors on time trends in non-Hodgkin's lymphoma incidence. Cancer Res. 1992; 52(19 Suppl): 5566s-9s.

11. Offit K, Wong G, Filippa DA, Tao Y, Chaganti RS. Cytogenetic analysis of 434 consecutively ascertained specimens of non-Hodgkin's lymphoma: clinical correlations. Blood. 1991; 77(7): 1508-15.

12. Lossos IS, Gascoyne RD. Transformation of follicular lymphoma. Best Pract Res Clin Haematol. 2011; 24(2): 147-63.

13. Lee JT, Innes Jr DJ, Williams ME. Sequential bcl-2 and c-myc oncogene rearrangements associated with the clinical transformation of non-Hodgkin's lymphoma. J Clin Invest. 1989; 84(5): 1454.

14. Ott G, Rosenwald A, Campo E. Understanding MYC-driven aggressive B-cell lymphomas: pathogenesis and classification. Blood. 2013; 122(24): 3884-91.

15. Vega F, Medeiros LJ. Chromosomal translocations involved in non-Hodgkin lymphomas. Arch Pathol Lab Med. 2003; 127(9): 1148-60.

16. Scarfò L, Ghia P. Reprogramming cell death: BCL2 family inhibition in hematological malignancies. Immuno Lett. 2013; 155(1): 36-9.

17. Wlodarska I, Nooyen P, Maes B, Martin-Subero JI, Siebert R, Pauwels P, et al. Frequent occurrence of BCL6 rearrangements in nodular lymphocyte predominance Hodgkin lymphoma but not in classical Hodgkin lymphoma. Blood. 2003; 101(2): 706-10.

18. Aukema SM, Siebert $R$, Schuuring E, van Imhoff GW, Kluin-Nelemans HC, Boerma EJ, et al. Double-hit B-cell lymphomas. Blood. 2011; 117(8): 2319-31.

19. Hans CP, Weisenburger DD, Greiner TC, Gascoyne RD, Delabie J, Ott G, et al. Confirmation of the molecular classification of diffuse large B-cell lymphoma by immunohistochemistry using a tissue microarray. Blood. 2004; 103(1): 275-82.

20. Al-Humood SA, Al-Qallaf AS, AlShemmari SH, Francis IM, Junaid TA Marouf RA, et al. Genotypic and phenotypic differences between nodal and extranodal diffuse large B-cell lymphomas. J Histochem Cytochem. 2011; 59(10): 918-31.

21. Isaacson $\mathrm{P}$, Wright $\mathrm{DH}$. Extranodal malignant lymphoma arising from mucosa-associated lymphoid tissue. Cancer. 1984; 53(11): 2515-24.

22. Küppers R. Mechanisms of B-cell lymphoma pathogenesis. Nat Rev Cancer. 2005; 5(4): 251-62.

23. Shaffer AL, Rosenwald A, Staudt LM. Lymphoid malignancies: the dark side of B-cell differentiation. Nat Rev Immunol. 2002; 2(12): 920-33.

24. Rosenquist R, Davi F, Stamatopoulos K. Antigens in lymphoma development-current knowledge and future directions. Semin cancer Bio. 2013; 23(6): 397-8.

25. Fadilah SA. Fundamentals of the management of non-Hodgkin lymphoma. Med J Malaysia. 2009; 64(4): 333-9.

26. Bacon CM. Extranodal lymphomas. Diagn Histopathol. 2010; 16(2): 82-98.

27. López-Guillermo A, Colomo L, Jiménez M, Bosch F, Villamor N, Arenillas L, et al. Diffuse large B-cell lymphoma: clinical and biological characterization and outcome according to the nodal or extranodal primary origin. J Clin Oncol. 2005; 23(12): 2797-804.

28. Guo Y, Karube K, Kawano R, Yamaguchi T, Suzumiya J, Huang GS, et al. Low-grade follicular lymphoma with $\mathrm{t}(14 ; 18)$ presents a homogeneous 
disease entity otherwise the rest comprises minor groups of heterogeneous disease entities with $\mathrm{Bcl} 2$ amplification, Bcl6 translocation or other gene aberrances. Leukemia. 2005; 19(6): 1058-63.

29. Leich E, Hoster E, Wartenberg M, Unterhalt M, Siebert R, Koch K, et al. Similar clinical features in follicular lymphomas with and without breaks in the BCL2 locus. Leukemia. 2016; 30(4): 854-60.

30. Aster JC, Longtine JA. Detection of BCL2 rearrangements in follicular lymphoma. Am J Pathol. 2002; 160(3): 759-63.

31. McDonnell TJ, Deane N, Platt FM, Nunez G, Jaeger U, McKearn JP, et al. bcl-2-immunoglobulin transgenic mice demonstrate extended B cell survival and follicular lymphoproliferation. Cell. 1989; 57(1): 79-88.

32. Marin MC, Hsu B, Stephens LC, Brisbay S, McDonnell TJ. The functional basis of c-myc and bcl-2 complementation during multistep lymphomagenesis in vivo. Exp Cell Research. 1995; 217(2): 240-7.

33. Tanaka H, Hashimoto S, Abe D, Sakai S, Takagi T. Double-hit lymphoma at second relapse of Burkitt-like lymphoma: a case report. J Clin Exp Hematop. 2011; 51(1): 43-7.

34. Iqbal J, Neppalli VT, Wright G, Dave BJ, Horsman DE, Rosenwald A, et al. BCL2 expression is a prognostic marker for the activated B-cell-like type of diffuse large B-cell lymphoma. J Clin Oncol. 2006; 24(6): 961-8.

35. Tibiletti MG, Martin V, Bernasconi B, Del Curto B, Pecciarini L, Uccella S, et al. BCL2, BCL6, MYC, MALT 1, and BCL10 rearrangements in nodal diffuse large B-cell lymphomas: a multicenter evaluation of a new set of fluorescent in situ hybridization probes and correlation with clinical outcome. Hum Pathol. 2009; 40(5): 645-52.

36. Teoh SH, Khoo JJ, Datu Abdul Salam DS, Peh SC, Cheah SC. pSTAT3 and MYC in Epstein-Barr virus-positive Diffuse Large B-cell Lymphoma. Malays J Pathol; in press

37. Dang CV. c-Myc target genes involved in cell growth, apoptosis, and metabolism. Mol Cell Bio. 1999;19(1):1-11.

38. Rooney N, Foster L, Byers R. Nodal B-cell lymphoma and Hodgkin lymphoma: current WHO classification and differential diagnostic dilemmas. Diagn Histopathol. 2010; 16(2): 54-68.

39. Slack GW, Gascoyne RD. MYC and aggressive B-cell lymphomas. Adv Anat Pathol. 2011; 18(3): 219-28.

40. Muramatsu M, Akasaka T, Kadowaki N, Ohno H, Yamabe H, Edamura S, et al. Rearrangement of the BCL6 gene in B-cell lymphoid neoplasms: comparison with lymphomas associated with BCL2 rearrangement. Br J Haematol. 1996; 93(4): 911-20.

41. Kramer MH, Hermans J, Wijburg E, Philippo K, Geelen E, van Krieken JH, et al. Clinical relevance of BCL2, BCL6, and MYC rearrangements in diffuse large B-cell lymphoma. Blood. 1998; 92(9): 3152-62.

42. Offit K, Louie DC, Parsa NZ, Roy P, Leung D, Lo Coco F, et al. BCL6 gene rearrangement and other cytogenetic abnormalities in diffuse large cell lymphoma. Leuk Lymphoma. 1995; 20(1-2): 85-9.

43. Kim MK, Bae SH, Bae YK, Kum YS, Ryoo HM, Cho HS, Lee KH, et al. Biological characterization of nodal versus extranodal presentation of diffuse large B-Cell lymphoma using immunohistochemistry. Clin Lymphoma Myeloma Leuk. 2011; 11(5): 403-8.

44. Migliazza A, Martinotti S, Chen W, Fusco C, Ye BH, Knowles DM, et al. Frequent somatic hypermutation of the 5' noncoding region of the BCL6 gene in B-cell lymphoma. Proc Natl Acad Sci USA. 1995; 92(26): 12520-4.

45. Ohno H, Fukuhara S. Significance of rearrangement of the BCL6 gene in B-cell lymphoid neoplasms. Leuk Lymphoma. 1997; 27(1-2): 53-63.

46. Gollub W, Stassek B, Huckhagel T, Bernd HW, Krokowski M, Merz H, et al. BCL6-translocations affect the phenotype of follicular lymphomas only in the absence of $\mathrm{t}(14 ; 18) \mathrm{IgH} / \mathrm{BCL} 2$. Anticancer Res. 2009; 29(11): 4649-55.

47. Cattoretti G, Pasqualucci L, Ballon G, Tam W, Nandula SV, Shen Q et al. Deregulated BCL6 expression recapitulates the pathogenesis of human diffuse large B cell lymphomas in mice. Cancer cell. 2005; 7(5): 445-55.

48. Bihui HY, Cattoretti G, Shen Q, Zhang J, Hawe N, de Waard R, et al. The BCL-6 proto-oncogene controls germinal-centre formation and Th2-type inflammation. Nat Genet. 1997; 16(2): 161-70.

49. Akasaka T, Akasaka H, Ueda C, Yonetani N, Maesako Y, Shimizu A, et al. Molecular and clinical features of non-Burkitt's, diffuse large-cell lymphoma of B-cell type associated with the c-MYC/immunoglobulin heavy-chain fusion gene. J Clin Oncol. 2000; 18(3): 510.

50. Barrans SL, O'Connor SJ, Evans PA, Davies FE, Owen RG, Haynes AP, et al. Rearrangement of the BCL6 locus at $3 q 27$ is an independent poor prognostic factor in nodal diffuse large B-cell lymphoma. Br J Haematol. 2002; 117(2): $322-32$.

51. Chen $\mathrm{YW}, \mathrm{Hu}$ XT, Liang $\mathrm{AC}, \mathrm{Au} W \mathrm{~W}$, So CC, Wong ML, et al. High BCL6 expression predicts better prognosis, independent of BCL6 translocation status, translocation partner, or BCL6-deregulating mutations, in gastric lymphoma. Blood. 2006; 108(7): 2373-83.

52. Akyurek N, Uner A, Benekli M, Barista I. Prognostic significance of MYC, BCL2, and BCL6 rearrangements in patients with diffuse large B-cell lymphoma treated with cyclophosphamide, doxorubicin, vincristine, and prednisone plus rituximab. Cancer. 2012; 118(17): 4173-83.

53. van Zelm MC, van der Burg M, de Ridder D, Barendregt $\mathrm{BH}$, de Haas EF, Reinders MJ, et al. Ig gene rearrangement steps are initiated in early human precursor B cell subsets and correlate with specific transcription factor expression. J Immunol. 2005; 175(9): 5912-22

54. Vettermann C, Schlissel MS. Allelic exclusion of immunoglobulin genes: models and mechanisms. Immunol Rev. 2010; 237(1): 22-42.
55. Green TM, Young $\mathrm{KH}$, Visco $\mathrm{C}$, Xu-Monette $\mathrm{ZY}$, Orazi A, Go RS, et al. Immunohistochemical double-hit score is a strong predictor of outcome in patients with diffuse large B-cell lymphoma treated with rituximab plus cyclophosphamide, doxorubicin, vincristine, and prednisone. J Clin Oncol. 2012;30(28):3460-7

56. Horn H, Ziepert M, Becher C, Barth TF, Bernd HW, Feller AC, et al. MYC status in concert with BCL2 and BCL6 expression predicts outcome in diffuse large B-cell lymphoma. Blood. 2013; 121(12): 2253-63.

57. Diaz-Alderete A, Doval A, Camacho F, Verde L, Sabin P, Arranz-Sáez R, et al. Frequency of BCL2 and BCL6 translocations in follicular lymphoma: relation with histological and clinical features. Leuk Lymphoma. 2008; 49(1): 95-101.

58. Keller CE, Nandula S, Fisher J, Subramaniyam S, Vakiani E, Savage DG, et al. The spectrum of B-cell non-Hodgkin lymphomas with dual IgH-BCL2 and BCL6 translocations. Am J Clin Pathol. 2008; 130(2): 193-201.

59. Gollub W, Stassek B, Huckhagel T, Bernd HW, Krokowski M, Merz H, et al. BCL6-translocations affect the phenotype of follicular lymphomas only in the absence of $\mathrm{t}(14 ; 18) \mathrm{IgH} / \mathrm{BCL} 2$. Anticancer Res. 2009; 29(11): 4649-55.

60. Pfreundschuh M. Growing importance of MYC/BCL2 immunohistochemistry in diffuse large B-cell lymphomas. J Clin Oncol. 2012; 30(28): 3433-5.

61. Tagawa H, Suguro M, Tsuzuki S, Matsuo K, Karnan S, Ohshima K, et al. Comparison of genome profiles for identification of distinct subgroups of diffuse large B-cell lymphoma. Blood. 2005; 106(5): 1770-7.

62. Shiozawa E, Yamochi-Onizuka T, Takimoto M, Ota H. The GCB subtype of diffuse large B-cell lymphoma is less frequent in Asian countries. Leuk Res. 2007; 31(11): 1579-83. 